\title{
MODEL PENDIDIKAN KEPRAMUKAAN INDONESIA DALAM PERSPEKTIF FILSAFAT PENDIDIKAN PAULO FREIRE
}

\section{Rusli Akhmad Junaedi}

Fakultas Filsafat, Universitas Gadjah Mada

Email: rusliakhmadjunaedi@gmail.com

\section{Abstrak}

Penelitian ini bertujuan mendeskripsikan model pendidikan kepramukaan Indonesia, mendeskripsikan pokok pemikiran filsafat pendidikan Paulo Freire, dan merefleksikan model pendidikan kepramukaan Indonesia dalam perspektif filsafat pendidikan Paulo Freire. Penelitian ini dilatarbelakangi oleh pro dan kontra Peraturan Menteri Pendidikan dan Kebudayaan Republik Indonesia No. 63 Tahun 2014 tentang Pendidikan Kepramukaan sebagai Ekstrakurikuler Wajib pada Pendidikan Dasar dan Pendidikan Menengah. Hasil penelitian ini adalah pendidikan kepramukaan merupakan proses belajar mandiri yang progresif bagi kaum muda untuk mengembangkan diri pribadi seutuhnya. Konsep filsafat pendidikan Paulo Freire merupakan konsep pendidikan pembebasan. Tujuan akhir keberadaan manusia adalah proses humanisasi, yaitu memanusiakan manusia. Hakikat model pendidikan kepramukaan Indonesia secara umum merupakan pendidikan yang bersifat dialogis dengan hubungan intersubjektivitas. Dehumansiasi yang terdapat pada model pendidikan kepramukaan Indonesia terjadi ketika ditetapkannya peraturan pendidikan kepramukaan sebagai ekstrakurikuler wajib, karena kesukarelaan dan kebebasan peserta didik dicederai dengan unsur paksaan untuk wajib mengikuti pendidikan kepramukaan sehingga praktik pendidikan hadap-masalah yang terdapat pada model pendidikan kepramukaan Indonesia menjadi terdistorsi.

Kata kunci: humanisasi, kepramukaan, manusia, pendidikan

\section{Abstract}

This research examines the model of Indonesia scouting education by employing Paulo Freire's perspective on philosophy of education. As an object of analysis, the research discusses the debated on the Regulation of Minister of Education and Culture of the Republic of Indonesia No. 63 of 2014 
concerning Scouting Education as a Mandatory Extracurricular in Primary and Secondary Education. The result of this study shows that scouting education in Indonesia is a progressive self-learning process for the youth to fully develop themselves. Paulo Freire's philosophy of education is a concept of education for liberation. It lays in the premise that the ultimate goal of human existence is the process of humanization. The paper argues that, in general, the character of Indonesian scouting education model is dialogical education which involves intersubjectivity process of education. It becomes de-humanizing education practice when the regulation of scouting education as a mandatory extracurricular activity is enacted. The mandatory regulation forces students' participation in the scouting education, whereby damaging the volunteerism and freedom dimension of education activities. By doing so, the mandatory regulation distorts the problem-posing education strategy already existing in the Indonesian scouting practices.

Keywords: humanization, scouting, people, education

\section{PENDAHULUAN}

Pada tahun 2014, pendidikan kepramukaan ditetapkan sebagai kegiatan ekstrakurikuler wajib dalam Peraturan Menteri Pendidikan dan Kebudayaan RI No. 63. Namun, peraturan pendidikan kepramukaan sebagai ekstrakurikuler wajib pada pendidikan dasar dan pendidikan menengah masih menjadi masih pro dan kontra. Persoalan terkait ditetapkannya pendidikan kepramukaan sebagai ekstrakurikuler wajib pada pendidikan dasar dan pendidikan menengah pernah dikritisi oleh Nurul Huda SA (Direktur Yayasan Fahmina Cirebon dan Pengurus Dewan Pendidikan Kota Cirebon, Jawa Barat) dalam tulisan yang dipublikasikan oleh tempo.co dengan judul Kebijakan Sesat: Pramuka dalam Kurikulum 2013. Menurut Huda, menempatkan Pramuka sebagai kewajiban untuk siswa di sekolah adalah pelanggaran atas hakikat Pramuka, merendahkan martabat Pramuka, melanggar UU No. 12 Tahun 2010 tentang Gerakan Pramuka, melanggar UU No. 20 Tahun 2003 tentang Sistem Pendidikan Nasional, bahkan menyalahi nalar akademik (tempo.co, 2013).

Peraturan Menteri Pendidikan dan Kebudayaan No. 63 Tahun 2014 tentang Pendidikan Kepramukaan sebagai Ekstrakurikuler Wajib 
pada Pendidikan Dasar dan Pendidikan Menengah dinilai melanggar Pasal 20 ayat 1 UU No. 12 Tahun 2010 yang berbunyi “Gerakan Pramuka bersifat mandiri, sukarela, dan nonpolitis". Pendidikan kepramukaan sebagai ekstrakurikuler wajib dianggap menyalahi prinsip sukarela yang terdapat dalam Gerakan Pramuka. Adanya peraturan tersebut membuat manusia, khususnya peserta didik mengalami dehumanisasi. Dehumanisasi terjadi ketika peserta didik kehilangan kebebasan untuk menentukan materi atau kursus yang mereka ikuti atas dasar kesadaran dan kemauannya sendiri. Dehumanisasi peserta didik merupakan bentuk penindasan sebab peran peserta didik sebagai subjek pendidikan berubah menjadi objek pendidikan.

Bila dilihat lebih jauh, pada satu sisi pendidikan kepramukaan sejak awal dibentuk hingga sekarang memiliki peranan yang penting terhadap pengembangan pendidikan karakter di Indonesia. Penyelenggaraan PPK (Penguatan Pendidikan Karakter) dalam kegiatan ekstrakurikuler merupakan penguatan nilai-nilai karakter dalam perluasan potensi, bakat, minat, kemampuan kepribadian, kerja sama, dan kemandirian peserta didik secara optimal (Peraturan Presiden Republik Indonesia No. 87 Tahun 2017).

Aspek legalitas Gerakan Pramuka yang jelas terdapat pada UU No. 12 Tahun 2010 turut mendorong pemerintah melakukan kerja sama dengan Gerakan Pramuka dalam rangka meningkatkan partisipasi peserta didik dalam kegiatan kepramukaan dengan menetapkan Peraturan Menteri Pendidikan dan Kebudayaan RI No. 63 Tahun 2014 tentang Pendidikan Kepramukaan sebagai Ekstrakurikuler Wajib pada Pendidikan Dasar dan Pendidikan Menengah. Peraturan tersebut mengarah pada tujuan Kementerian Pendidikan dan Kebudayaan terkait terwujudnya insan dan warga negara Indonesia dalam konteks nilai dan moral Pancasila.

Namun di sisi lain, perubahan model pendidikan kepramukaan sebagai ekstrakurikuler wajib pada pendidikan dasar dan pendidikan menengah berdampak pada dehumanisasi peserta didik. Kesukarelaan dan kebebasan peserta didik dicederai dengan unsur paksaan untuk wajib mengikuti pendidikan kepramukaan.

Paulo Freire seorang filsuf dan ahli teori pendidikan (dalam 
Murtiningsih, 2004: 10) mengatakan pendidikan bukanlah wujud dari penindasan. Pendidikan justru mampu menyadarkan pemaksaan dan penindasan itu bukan hanya sekadar fisik, melainkan dapat merasuk ke dalam kesadaran manusia. Pendidikan bertujuan membina kepribadian manusia dan tugas utama pendidikan adalah membebaskan diri dari penindasan yang tak disadari.

Kemanusiaan yang telah dirampas atau dehumanisasi merupakan pembengkokan cita-cita untuk menjadi manusia yang lebih utuh. Distorsi ini terjadi dalam sejarah, namun bukan fitrah sejarah. Perjuangan menjadi mungkin, karena dehumanisasi bukan takdir manusia, namun produk tatanan yang tidak adil sehingga melahirkan kekerasan para penindas yang pada gilirannya mengubah kaum tertindas menjadi manusia yang tidak utuh (Freire, 2008: 1213).

Melihat fenomena pro dan kontra peraturan pendidikan kepramukaan sebagai ekstrakurikuler wajib pada pendidikan dasar dan pendidikan menengah, maka penelitian ini menjadi penting untuk merefleksikan model pendidikan kepramukaan Indonesia dalam perspektif filsafat pendidikan Paulo Freire. Permasalahan dehumanisasi yang terdapat pada model pendidikan kepramukan Indonesia layak dikaji dengan sudut pandang filsafat pendidikan Paulo Freire untuk memberikan jawaban filosofis tentang ruang lingkup pendidikan, khususnya terkait dengan masalah dehumanisasi yang terdapat pada model pendidikan kepramukaan Indonesia.

\section{FILSAFAT PENDIDIKAN PAULO FREIRE Humanisasi dan Dehumanisasi}

Humanisasi merupakan poin penting dari pendidikan pembebasan. Sejarah telah membuktikan hal ini adalah panggilan manusia yang sejati. Humanisasi sering disangkal, diputarbalikan, dan dieksploitasi sehingga terjadi kekerasan terhadap kaum tertindas. Muncul kerinduan kaum tertindas terhadap kebebasan dan keinginannya untuk merebut kembali kemanusiaannya yang hilang atau terampas. Kemanusiaan yang telah dirampas atau dehumanisasi merupakan pembengkokan cita-cita untuk menjadi manusia yang 
lebih utuh. Distorsi ini terjadi dalam sejarah, namun bukan fitrah sejarah. Perjuangan menjadi mungkin, karena dehumanisasi bukan takdir manusia namun produk tatanan yang tidak adil sehingga melahirkan kekerasan para penindas yang pada gilirannya mengubah kaum tertindas menjadi manusia yang tidak utuh (Freire, 2008: 1213).

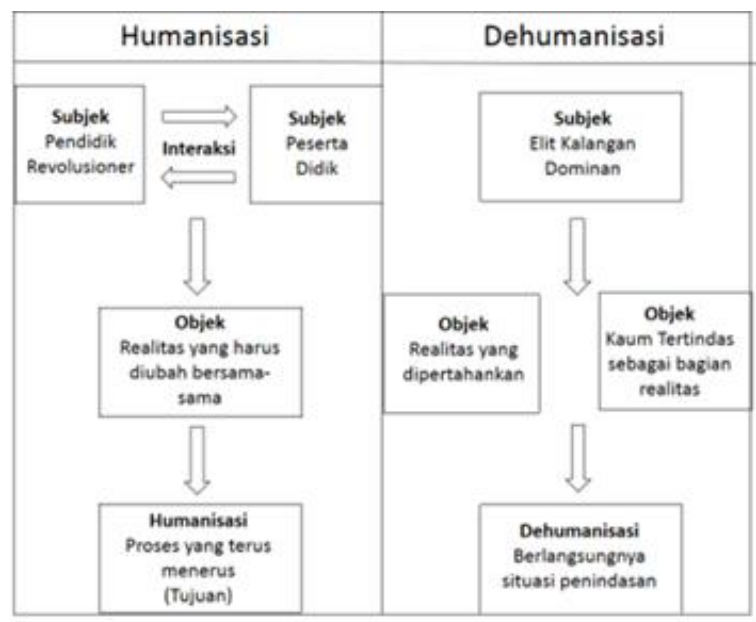

Gambar 1. Perbedaan Humanisasi dan Dehumanisasi

Sumber: Freire, 1999: xvi

Bagi Freire tujuan akhir atas keberadaan manusia adalah proses humanisasi, yaitu memanusiakan manusia. Proses ini dapat terwujud jika manusia berinteraksi dengan dunia. Dalam berinteraksi dengan dunia manusia mengalami masalah, yakni saat manusia mengalami sejarah, manusia menemukan kondisi untuk menuju kebebasan tidak tercapai. Manusia hanya berhenti pada tahap evolusi yang mengakibatkan sebagian besar manusia teraleniasi. Permasalahan utama untuk menjadi manusia seutuhnya adalah masalah pembebasan dari keterasingan. Proses pembebasan dan humanisasi harus melibatkan kesadaran yang telah muncul dan praksis sebagai dampak dari kesadaran yang semakin tinggi. Pembebasan bukanlah keadaan statis yang terakhir, melainkan transformasi secara terus-menerus dan permanen atas realitas yang mendukung pembebasan manusia sehingga proses transformasi 
mampu menghadirkan manusia baru dalam proses pembebasan. Tujuan humanisasi adalah tujuan sosial dan kebutuhan manusia untuk menjadi makhluk bagi dirinya sendiri tercapai saat masyarakat mampu menjadi sesuatu untuk dirinya sendiri (Collins, 1999: 120).

\section{Pendidikan Hadap-Masalah}

Dalam pendidikan hadap-masalah, manusia mengembangkan kemampuannya untuk memahami secara kritis cara manusia mengada dalam dunia. Manusia memandang dunia bukan sebagai realitas yang statis, tetapi sebagai realitas yang berada dalam proses. Pendidikan sebagai praksis pembebasan yang manusiawi menganggap hal yang paling mendasar, yakni manusia korban penindasan harus berjuang bagi pembebasan dirinya (Freire, 2008: 70-73).

Secara garis besar, perbedaan kedua model pendidikan tersebut dapat dilihat dalam Tabel berikut (Freire, 2008: 69-70).

Tabel 1. Perbedaan Pendidikan Penindasan dan Pendidikan Pembebasan

\begin{tabular}{|l|l|}
\hline \multicolumn{1}{|c|}{ Pendidikan Penindasan } & \multicolumn{1}{c|}{ Pendidikan Pembebasan } \\
\hline $\begin{array}{l}\text { Berusaha dengan cara memitoskan } \\
\text { realitas serta menyembunyikan } \\
\text { fakta-fakta tertentu yang } \\
\text { menjelaskan cara manusia } \\
\text { mengada di dunia. }\end{array}$ & $\begin{array}{l}\text { Memilih sendiri untuk } \\
\text { menghapuskan mitos tersebut }\end{array}$ \\
\hline Menolak dialog & $\begin{array}{l}\text { Dialog merupakan prasyarat bagi } \\
\text { laku pemahaman untuk } \\
\text { menguak realitas }\end{array}$ \\
\hline $\begin{array}{l}\text { Memperlakukan murid sebagai } \\
\text { objek yang harus ditolong }\end{array}$ & $\begin{array}{l}\text { Memperlakukan murid sebagai } \\
\text { pemikir yang kritis }\end{array}$ \\
\hline
\end{tabular}




\begin{tabular}{|c|c|}
\hline $\begin{array}{l}\text { Menghalang-halangi kreativitas } \\
\text { dan menjinakkan intensionalitas } \\
\text { kesadaran dengan cara } \\
\text { mengisolasi kesadaran itu dari } \\
\text { dunia sehingga menolak untuk } \\
\text { menjadi manusia seutuhnya. }\end{array}$ & $\begin{array}{l}\text { Mendasari dirinya atas } \\
\text { kreativitas serta mendorong } \\
\text { refleksi dan tindakan yang benar } \\
\text { atas realitas, maka dengan cara } \\
\text { tersebut menyambut fitrah } \\
\text { manusia yang akan menjadi } \\
\text { makhluk sejati manakala terlibat } \\
\text { dalam pencarian dan perubahan } \\
\text { kreatif. }\end{array}$ \\
\hline $\begin{array}{l}\text { Teori dan praktik pendidikannya } \\
\text { merupakan kekuatan yang } \\
\text { membelenggu dan menekan } \\
\text { sehingga membuat } \\
\text { ketidakmampuan dalam } \\
\text { menampilkan manusia sebagai } \\
\text { makhluk yang menyejarah. }\end{array}$ & $\begin{array}{l}\text { Teori dan praktik pendidikannya } \\
\text { menjadi kesejarahan manusia } \\
\text { sebagai pangkal tolak serta } \\
\text { menegaskan manusia sebagai } \\
\text { makhluk yang berada dalam } \\
\text { proses menjadi sebagai sesuatu } \\
\text { yang tidak pernah selesai, } \\
\text { makhluk yang tidak pernah } \\
\text { sempurna dalam dan dengan } \\
\text { realitas yang juga tidak pernah } \\
\text { selesai. }\end{array}$ \\
\hline
\end{tabular}

\section{Konsientisasi}

Konsientisasi bukanlah teknik untuk transfer informasi atau bahkan untuk pelatihan keterampilan, tetapi merupakan proses dialogis yang mengantarkan individu-individu secara bersama-sama memecahkan masalah eksistensial mereka. Konsientisasi mengemban tugas pembebasan dan pembebasan itu berarti penciptaan norma, aturan, prosedur, dan kebijakan baru. Pembebasan bermakna transformasi atas sistem realitas yang saling terkait dan kompleks serta reformasi beberapa individu untuk mereduksi konsekuensikonsekuensi negatif dan perilakunya. Meskipun kesadaran atas situasi manusia-dunia yang sudah dikembangkan membuat manusia menyadari keadaan ketertindasannya. Hal ini belum dapat dikatakan sebagai konsientisasi. Kesadaran ini merupakan langkah pertama 
menuju konsientisasi, yaitu kesadaran yang berada dalam situasi the prise de conscience (Smith, 2008: 4).

Proses konsientisasi dibagi menjadi tiga fase, yaitu kesadaran magis, kesadaran naif, dan kesadaran kritis (Smith, 2008: 54). Ketiga fase kesadaran yang berbeda ini memiliki hubungan. Tingkatantingkatan kesadaran tersebut bukan hanya bentukan individu, tetapi juga hasil dari lingkungan tempat individu tersebut hidup dan faktorfaktor sejarah serta budaya yang diciptakan oleh lingkungan.

Terkait dengan garis besar perkembangan proses konsientisasi dapat dilihat pada Tabel 2 berikut (Smith, 2008: 97-101).

Tabel 2. Garis Besar Fase Perkembangan Proses Konsientisasi

\begin{tabular}{|l|l|l|l|}
\hline $\begin{array}{l}\text { Tingkat } \\
\text { Kesadaran }\end{array}$ & Kesadaran Magis & Kesadaran Naif & Kesadaran Kritis \\
\hline Penamaan & $\begin{array}{l}\text { Penolakan } \\
\text { terhadap } \\
\text { Masalah }\end{array}$ & $\begin{array}{l}\text { Penyimpangan } \\
\text { Individu Tertindas }\end{array}$ & $\begin{array}{l}\text { Menolak } \\
\text { Penindas/ } \\
\text { Penegasan Diri }\end{array}$ \\
\cline { 2 - 4 } a. Menolak Tegas & $\begin{array}{l}\text { a. Individu-individu } \\
\text { tertindas tidak suka } \\
\text { pada penindas }\end{array}$ & $\begin{array}{l}\text { a. Menolak untuk } \\
\text { meniru penindas }\end{array}$ \\
\cline { 2 - 4 } & $\begin{array}{l}\text { b. Menghindari } \\
\text { Masalah } \text { Individu tertindas } \\
\text { tidak memenuhi } \\
\text { keinginan penindas }\end{array}$ & $\begin{array}{l}\text { b. Memelihara } \\
\text { Entitas }\end{array}$ \\
\cline { 2 - 5 } & $\begin{array}{l}\text { Masalah } \\
\text { Bertahan Hidup }\end{array}$ & $\begin{array}{l}\text { Penyimpangan } \\
\text { Individu Tertindas }\end{array}$ & $\begin{array}{l}\text { Mengubah Sistem } \\
\text { Keunikan }\end{array}$ \\
\cline { 2 - 5 } & $\begin{array}{l}\text { a. Kesehatan } \\
\text { Buruk }\end{array}$ & $\begin{array}{l}\text { a. Penindas } \\
\text { Melanggar Hukum }\end{array}$ & $\begin{array}{l}\text { a. Prosedur } \\
\text { (masyarakat) }\end{array}$ \\
\cline { 2 - 4 } & b. Kemiskinan & $\begin{array}{l}\text { b. Penindas } \\
\text { Melanggar Norma }\end{array}$ & $\begin{array}{l}\text { b. Menolak Sistem } \\
\text { yang Menindas }\end{array}$ \\
\cline { 2 - 5 } & c. Pengangguran & & \\
\cline { 2 - 4 } & $\begin{array}{l}\text { d. Pekerjaan yang } \\
\text { Tidak } \\
\text { Mencukupi }\end{array}$ & & \\
\hline
\end{tabular}




\begin{tabular}{|c|c|c|c|}
\hline & $\begin{array}{l}\text { e. Uang Habis } \\
\text { dengan } \\
\text { Sendirinya }\end{array}$ & & \\
\hline \multirow[t]{8}{*}{ Berpikir } & $\begin{array}{l}\text { Interelasi } \\
\text { Kausalitas yang } \\
\text { Sederhana }\end{array}$ & $\begin{array}{l}\text { Menyalahkan } \\
\text { Sesama Kaum } \\
\text { Tertindas }\end{array}$ & $\begin{array}{l}\text { Mengetahui dan } \\
\text { Menolak Ideologi } \\
\text { Penindas dan } \\
\text { Kolusi }\end{array}$ \\
\hline & $\begin{array}{l}\text { a. Menyalahkan } \\
\text { keadaan fisik } \\
\text { (kesehatan) }\end{array}$ & $\begin{array}{l}\text { a. Menerima } \\
\text { penjelasan atau } \\
\text { keinginan penindas } \\
\text { (pendidikan sebagai } \\
\text { tujuan itu sendiri) }\end{array}$ & $\begin{array}{l}\text { a. Simpati dan } \\
\text { memahami sesama } \\
\text { kaum tertindas }\end{array}$ \\
\hline & $\begin{array}{l}\text { b. Menyalahkan } \\
\text { objek-objek yang } \\
\text { bukan orang- } \\
\text { orang }\end{array}$ & $\begin{array}{l}\text { b. Konflik dengan } \\
\text { sesama }\end{array}$ & $\begin{array}{l}\text { b. Mengkritik diri } \\
\text { (mengetahui } \\
\text { kontradiksi antara } \\
\text { aksi dan tujuan } \\
\text { kritis) }\end{array}$ \\
\hline & & $\begin{array}{l}\text { c. Menyalahkan } \\
\text { nenek moyang }\end{array}$ & $\begin{array}{l}\text { c. Menolak agresi } \\
\text { horizontal } \\
\text { (menengaskan } \\
\text { diri) }\end{array}$ \\
\hline & & $\begin{array}{l}\text { d. Kasihan pada diri } \\
\text { sendiri }\end{array}$ & $\begin{array}{l}\text { d. Mengetahui } \\
\text { penindas sebagai } \\
\text { korban sistem }\end{array}$ \\
\hline & & & $\begin{array}{l}\text { e. Menggeneralisir } \\
\text { satu kelompok } \\
\text { penindas pada } \\
\text { kelompok lain }\end{array}$ \\
\hline & $\begin{array}{l}\text { Fakta-fakta yang } \\
\text { Diserahkan } \\
\text { kepada Penguasa }\end{array}$ & $\begin{array}{l}\text { Mengetahui } \\
\text { Bagaimana Penindas } \\
\text { Melanggar Norma }\end{array}$ & $\begin{array}{l}\text { Mengetahui } \\
\text { Bagaimana Kerja } \\
\text { Sistem }\end{array}$ \\
\hline & $\begin{array}{l}\text { a. Faktor-faktor } \\
\text { yang tidak } \\
\text { terkendali } \\
\text { (Tuhan, nasib, } \\
\text { keberuntungan, } \\
\text { usia, dll) }\end{array}$ & $\begin{array}{l}\text { a. Mengetahui } \\
\text { maksud penindas }\end{array}$ & $\begin{array}{l}\text { a. Mengetahui } \\
\text { sistem sebagai } \\
\text { penyebab }\end{array}$ \\
\hline
\end{tabular}




\begin{tabular}{|c|c|c|c|}
\hline & $\begin{array}{l}\text { b. Takut pada } \\
\text { penindas }\end{array}$ & $\begin{array}{l}\text { b. Mengetahui } \\
\text { hubungan diantara } \\
\text { penindas atau agen- } \\
\text { agennya }\end{array}$ & $\begin{array}{l}\text { b. Mengetahui } \\
\text { kontradiksi antara } \\
\text { retorika dan } \\
\text { kenyataan }\end{array}$ \\
\hline & $\begin{array}{l}\text { c. Penindas selalu } \\
\text { menjadi } \\
\text { pemenang }\end{array}$ & $\begin{array}{l}\text { c. Menggenaralisasi- } \\
\text { kan satu penindas } \\
\text { pada semuanya }\end{array}$ & $\begin{array}{l}\text { c. Analisis sosio- } \\
\text { ekonomi makro }\end{array}$ \\
\hline & $\begin{array}{l}\text { d. Empati kepada } \\
\text { Penindas }\end{array}$ & & $\begin{array}{l}\text { d. Menggeneralisir } \\
\text { sistem yang } \\
\text { menindas pada } \\
\text { sistem lain }\end{array}$ \\
\hline \multirow[t]{7}{*}{ Aksi } & Fatalisme & $\begin{array}{l}\text { Aktif Bekerja sama } \\
\text { dengan Penindas } \\
\text { (Kolusi) }\end{array}$ & Aktualisasi Diri \\
\hline & a. Penarikan diri & $\begin{array}{l}\text { a. Meniru perilaku } \\
\text { penindas } \\
\text { (pendidikan, } \\
\text { pakaian, dan } \\
\text { kebiasaan) }\end{array}$ & $\begin{array}{l}\text { a. Mencari model- } \\
\text { model peran yang } \\
\text { sesuai }\end{array}$ \\
\hline & b. Menerima & $\begin{array}{l}\text { b. Agresi salah arah } \\
\text { (agresi horizontal } \\
\text { dan penghakiman } \\
\text { sendiri) }\end{array}$ & b. Menghargai diri \\
\hline & & $\begin{array}{l}\text { c. Bersikap } \\
\text { paternalistik } \\
\text { terhadap sesama }\end{array}$ & $\begin{array}{l}\text { c. } \\
\text { Mengembangkan } \\
\text { diri (mencari } \\
\text { pengetahuan) }\end{array}$ \\
\hline & & $\begin{array}{l}\text { d. Memenuhi } \\
\text { keinginan penindas }\end{array}$ & d. Menjadi subjek \\
\hline & & $\begin{array}{l}\text { e. Mengubah } \\
\text { keadaan }\end{array}$ & $\begin{array}{l}\text { e. Menerapkan } \\
\text { solusi baru secara } \\
\text { tegas (berani } \\
\text { mengambil risiko) }\end{array}$ \\
\hline & & & $\begin{array}{l}\text { f. Mengandalkan } \\
\text { sumber daya } \\
\text { komunitas } \\
\text { (partisipasi) }\end{array}$ \\
\hline
\end{tabular}




\begin{tabular}{|c|c|}
\hline & $\begin{array}{l}\text { g. Percaya pada } \\
\text { sesama (belajar } \\
\text { bersama) }\end{array}$ \\
\hline & $\begin{array}{l}\text { h. Menentang } \\
\text { kelompok- } \\
\text { kelompok } \\
\text { penindas }\end{array}$ \\
\hline $\begin{array}{l}\text { Menghidupi } \\
\text { Penindas secara } \\
\text { Pasif }\end{array}$ & Mengubah Sistem \\
\hline $\begin{array}{l}\text { a. Menunggu } \\
\text { "kebaikan: } \\
\text { keberuntungan } \\
\text { (patron) }\end{array}$ & $\begin{array}{l}\text { a. Mengedepankan } \\
\text { dialog daripada } \\
\text { polemik }\end{array}$ \\
\hline $\begin{array}{l}\text { b. Bergantung } \\
\text { pada penindas }\end{array}$ & b. Kerja sama \\
\hline & $\begin{array}{l}\text { c. Pendekatan } \\
\text { Ilmiah }\end{array}$ \\
\hline & $\begin{array}{l}\text { d. Mengubah } \\
\text { norma, prosedur, } \\
\text { dan hukum }\end{array}$ \\
\hline
\end{tabular}

Kesadaran magis merupakan kesadaran masyarakat yang tidak mampu melihat dan mengidentifikasi kaitan antara satu faktor pembentuk realitas dengan faktor yang lain. Manusia menyerah pada ketidakmampuannya melawan realitas yang menindas. Mereka tidak dapat mengetahui segala macam bentuk perubahan yang terjadi pada orang lain. Manusia hanya pasrah dan tunduk pada yang ada di sekitarnya. Mereka tidak memiliki kesadaran atau tuntutan untuk melakukan tindakan perlawanan atas realitas yang membelenggu. Manusia pada kesadaran magis dapat dikatakan sebagai manusia pasif yang hanya menerima realitas. Orang-orang dalam fase kesadaran magis menyesuaikan diri dengan kehidupan tempat tinggalnya. Mereka mendefinisikan masalah dengan mengkaitkannya pada persoalan-persoalan cara bertahan hidup dan merasa masalahmasalah ini disebabkan oleh kekuasaan-kekuasaan yang di luar jangkauan mereka. Tindakan-tindakan yang mereka lakukan 
terentang sejak dari menerima keadaan secara pasif sampai menggulingkan kekuasaan-kekuasaan yang mereka anggap membelenggu kehidupan mereka (Smith, 2008: 101).

Pada tingkatan kesadaran naif, manusia memiliki peran sebagai penyebab utama terjadinya realitas. Etika, kreativitas, dan kebutuhan akan kesuksesan dianggap sebagai penentu perubahan sosial. Kemiskinan yang terjadi di masyarakat dianggap sebagai kesalahan masyarakat tersebut. Masyarakat menganggap sistem dan struktur yang ada sudah baik dan benar serta hal tersebut merupakan faktor given, maka tidak perlu tindakan kritis untuk mempertanyakannya lagi. Individu tertindas ingin memperbaharui sistem yang telah dirusak oleh orang-orang jahat yang telah melanggar norma dan aturan. Pada tingkatan kesadaran ini dapat dibagi menjadi dua tingkatan sub-kesadaran, antara lain: (a) subkesadaran pertama, individu-individu menyalahkan diri mereka sendiri dan kawan-kawannya, karena dianggap telah melanggar norma sehingga memunculkan perasaan bersalah kemudian mengarah pada tindak kekerasan horizontal. Tindakan-tindakan mereka diarahkan mengubah diri mereka sendiri dan meniru penindas untuk lebih berpendidikan dan berkuasa; dan (b) subkesadaran kedua, individu-individu tertindas menyalahkan individu penindas atau kelompok penindas tertentu, karena melanggar normanorma yang ada. Mereka mengetahui bagaimana maksud dan betapa kasarnya perilaku penindas, tetapi mereka menimpakan penyebab persoalan ini pada individu penindas. Tindakan-tindakan mereka diarahkan untuk mempertahankan diri dari akibat buruk yang ditimbulkan oleh pelanggaran norma individu penindas (Smith, 2008: 102).

Puncak kesadaran manusia, yaitu kesadaran kritis merupakan titik tolak pemikiran Freire. Kesadaran ini melihat realitas secara sinergis antara manusia dan alam. Struktur dan sistem sosial menjadi sumber masalah yang diangkat oleh manusia yang mencapai kesadaran ini. Pendekatan struktural menghindari blaming the victim dan lebih menganalisis secara kritis struktur dan sistem sosial, politik, ekonomi, budaya, dan implikasinya terhadap kehidupan masyarakat. 
Individu-individu yang berkesadaran kritis menganggap pentingnya transformasi atas sistem sosial yang menindas (Smith, 2008: 102).

Akan tetapi, mengubah realitas secara mendasar tidak cukup dengan melakukan tambal-sulam terhadap hubungan antara penindas dan tertindas, karena penyebab penindasan ini adalah sistem, yakni seperangkat norma yang menguasai kaum tertindas dan penindas. Proses transformasi ini dimulai dengan menolak dan menyingkirkan ideologi penindas dan meningkatnya penghargaan terhadap diri sendiri dan kekuatan komunitas. Mereka berpikir secara ilmiah dan tidak lagi merujuk pada kasus-kasus penindasan, tetapi pada wilayah sosial-ekonomi makro tempat kehidupan berjalan dalam konteks global. Individu-individu yang kritis mulai mencari model-model peran baru mengandalkan kekuatan diri dan sumbersumber daya komunitas, keberanian mengambil risiko, dan independen terhadap penindas. Pendekatan baru dalam memecahkan masalah ini, yaitu polemik diganti dialog dengan kawan-kawannya menyebabkan individu tertindas harus memformulasikan tindakantindakannya sendiri yang berujung pada pembebasan dan transformasi yang sebenarnya (Smith, 2008: 103).

\section{Dialog dan Anti-Dialog}

Freire $(2008,75-76)$ pada hakikatnya mendefinisikan dialog sebagai kata yang tersusun dari dua dimensi, yaitu pikiran atau refleksi dan tindakan atau aksi yang keduanya tidak dapat terpisahkan. Bila salah satu dimensi dihilangkan, maka menjadi tidak bermakna. Kata yang kehilangan dimensi tindakannya, kata tersebut berubah menjadi omong kosong. Kata tersebut menjadi tidak mampu memberitakan dunia, karena pemberitaan tidak mungkin tanpa keterlibatan untuk mengubah dan tidak ada perubahan tanpa tindakan. Jika sebuah kata kehilangan dimensi refleksinya, maka kata itu berubah menjadi aktivisme, yaitu tindakan bagi tindakan itu sendiri tanpa mampu untuk dimaknai dalam konteks perubahan.

Dialog dan anti dialog dibangun atas berbagai unsur. Berikut gambaran Freire tentang perbedaan unsur-unsur yang ada dalam dialog dan anti dialog. Unsur-unsur dialog dan antidialog ini dapat dilihat di dalam Tabel 3 (Murtiningsih, 1995: 165-167). 
Tabel 3. Unsur-unsur Dialog dan Anti Dialog

\begin{tabular}{|l|l|}
\hline \multicolumn{1}{|c|}{ Dialog } & \multicolumn{1}{|c|}{ Anti Dialog } \\
\hline $\begin{array}{l}\text { Kerja sama; Setiap tahap } \\
\text { pendidik revolusioner dan } \\
\text { peserta didik harus dapat } \\
\text { bekerja sama dengan } \\
\text { mengandalkan kepercayaan } \\
\text { serta mengidentifikasi } \\
\text { bersama peserta didik. }\end{array}$ & $\begin{array}{l}\text { Penaklukan; hubungan } \\
\text { antarmanusia didasari atas } \\
\text { penaklukan. Manusia akan } \\
\text { berusaha untuk melenyapkan } \\
\text { kualitas manusia yang lain } \\
\text { sebagai alat pertimbangan } \\
\text { dunia sehingga kaum tertindas } \\
\text { akan terasingkan dari } \\
\text { dunianya. }\end{array}$ \\
\hline $\begin{array}{l}\text { Kesatuan; membebaskan } \\
\text { subjek dari pendidikan yang } \\
\text { membelenggu realitas serta } \\
\text { menaifkan kesadaran }\end{array}$ & $\begin{array}{l}\text { Pecah dan kuasai; supaya } \\
\text { dapat terus berkuasa, maka } \\
\text { kaum penindas harus memecah } \\
\text { belah kesatuan kaum tertindas. }\end{array}$ \\
\hline $\begin{array}{l}\text { Organisasi; kesaksian bagi } \\
\text { adanya kenyataan bahwa } \\
\text { perjuangan bagi pembebasan } \\
\text { adalah tugas bersama. }\end{array}$ & $\begin{array}{l}\text { Manipulasi; anak didik dibuat } \\
\text { menyesuaikan diri dengan } \\
\text { tujuan-tujuan dari para } \\
\text { pendidik yang antidialogis. }\end{array}$ \\
\hline $\begin{array}{l}\text { Sintesis Kultural; Pendidik } \\
\text { tidaklah datang sebagai orang } \\
\text { yang menyerang dan } \\
\text { menjinakan, akan tetapi orang } \\
\text { yang akan belajar bersama } \\
\text { anak didik mengenai } \\
\text { dunianya serta realitas } \\
\text { sesungguhnya sehingga } \\
\text { pendidik dan peserta didik } \\
\text { dapat mengidentifikasikan }\end{array}$ & $\begin{array}{l}\text { Serangan budaya; pendidikan } \\
\text { akan memaksakan pandangan } \\
\text { dunianya sendiri kepada } \\
\text { peserta didik sehingga } \\
\text { menghambat kreativitas } \\
\text { dengan mengendalikan } \\
\text { ungkapan-ungkapan kejiwaan } \\
\text { peserta didik. }\end{array}$ \\
\hline
\end{tabular}


diri kemudian melihat garisgaris besar bagi karyanya.

Dialog bagi Shor dan Freire (2001: 151) harus dipahami sebagai sesuatu yang terlibat di dalam sejarah umat manusia. Dialog adalah bagian dari kemajuan historis dalam menjadi manusia. Dialog merupakan postur yang niscaya sedemikian seingga manusia menjadi makhluk yang sangat komunikatif dan kritis. Dialog juga momen untuk merefleksikan realitas yang diciptakan atau diciptakan kembali.

\section{PENDIDIKAN KEPRAMUKAAN INDONESIA Sejarah Pendidikan Kepramukaan Indonesia}

Katamsi dkk (2001: 21) mengatakan beredarnya buku Scouting for Boys di luar Inggris, terutama di kawasan Eropa yang diikuti dengan berdirinya organisasi-organisasi kepanduan dengan cepat pula menyebar ke negeri-negeri lain, termasuk Belanda. Hindia Belanda (Indonesia) yang pada waktu itu sebagai jajahan Belanda. Pada awalnya, didirikan juga cabang dari gerakan kepanduan dari Negeri Belanda kemudian berkembang dan mandiri bernama Nederlands Indische Padvinders Vereniging (NIPV). Gerakan kepanduan ikut berperan aktif dalam Kongres Pemuda pada 28 Oktober 1928 yang mencetuskan Sumpah Pemuda. Sumpah Pemuda tersebut menjiwai gerakan kepanduan Indonesia pada waktu itu sehingga kepanduan Indonesia semakin berkembang dan menjadi bagian tak terpisahkan dari gerakan perjuangan kemerdekaan Indonesia. K.H. Agus Salim telah mencetuskan idenya dengan mengganti istilah Padvinder menjadi Pandu. Semasa penjajahan Jepang, gerakan kepanduan dilarang, namun idealisme dan semangat kepanduan tetap menjiwai para pandu.

Dalam perjuangan bangsa Indonesia untuk mencapai kemerdekaan, para anggota pandu terjun untuk bahu-membahu dengan pemuda merebut kemerdekaan dan mempertahankannya, bahkan sebagian besar memegang pucuk pimpinan ketentaraan. Panglima Besar Jendral Sudirman adalah salah seorang di antara 
mereka yang pernah berkiprah di dunia kepanduan. Demikian pula Sri Sultan Hamengku Buwono IX. Setelah Proklamasi Kemerdekaan Indonesia, semasa berkobarnya perang kemerdekaan, pada tanggal 28 Desember 1945 di Solo dibentuk Pandu Rakyat Indonesia sebagai satu-satunya organisasi kepanduan Indonesia. Keberadaan Pandu Rakyat Indonesia dikuatkan dengan Keputusan Menteri Pendidikan, Pengajaran, dan Kebudayaan No. 93/Bhg.A pada tanggal 1 Februari 1947 (Katamsi dkk, 2001: 24-25).

Pada awal tahun 1950, yaitu sesudah penyerahan kedaulatan, organisasi kepanduan yang sebelum Perang Dunia II pernah ada, seperti Hizbul Wathan, Serikat Islam Afdeling Pandu, Pandu Kristen, Pandu Katolik, Kepanduan Bangsa Indonesia, dan lainnya timbul kembali melakukan aktivitasnya sebagai organisasi kepanduan. Dalam keadaan demikian, Menteri PP dan K mencabut Keputusan No. 93/Bhg.A. Tahun 1947 dan menggantinya dengan Keputusan Menteri No. 23441/Kab tanggal 6 September 1951. Dengan penggantian Keputusan Menteri tersebut memungkinkan timbulnya organisasi-organisasi di samping Pandu Rakyat Indonesia (Katamsi dkk, 2001: 26).

Berbagai hasrat bersatu sebenarnya sangat besar dan tak terbendungkan lagi sehingga pada tanggal 16 September 1951 terbentuklah Ikatan Pandu Indonesia (IPINDO). IPINDO pada tahun 1953 diterima menjadi anggota organisasi kepanduan se-dunia mewakili Negara Kesatuan Republik Indonesia masuk dalam Far East Regional Scout Office. Pada tahun 1954 pandu golongan puteri membentuk Persaudaraan Organisasi Pandu Puteri Indonesia (POPPINDO) dan Persatuan Kepanduan Puteri Indonesia (PKPI). IPINDO sebagai federasi golongan putera itu kemudian berfederasi dengan golongan puteri dan terbentuklah PERKINDO (Persatuan Kepanduan Indonesia) pada tahun 1960 (Katamsi dkk, 2001: 26-27).

Kurun waktu tahun 1950-1960 organisasi kepanduan tumbuh semakin banyak jumlah dan ragamnya, bahkan di antaranya merupakan organisasi kepanduan yang berafiliasi pada partai politik. Hal ini tentunya menyalahi prinsip dasar dan metode kepramukaan. Keberadaan kepanduan seperti inni dinilai sangat tidak efektif dan tidak dapat mengimbangi perkembangan zaman serta kurang 
bermanfaat dalam mendukung pembangunan bangsa dan pembangunan generasi muda yang melestarikan persatuan dan kesatuan bangsa (Katamsi dkk, 2001: 31).

Memperhatikan keadaan yang demikian itu dan atas dorongan tokoh kepanduan saat itu serta bertolak dari ketetapan MPRS No. II/MPRS/1960, Presiden Soekarno selaku Mandataris MPRS pada tanggal 9 Maret 1961 memberikan amanat kepada pimpinan pandu di Istana Merdeka. Presiden Soekarno merasa berkewajiban melaksanakan amanat MPRS untuk lebih mengefektifkan organisasi kepanduan sebagai satu komponen bangsa yang potensial dalam pembangunan bangsa dan negara. Presiden Soekarno menyatakan pembubaran semua organisasi kepanduan di Indonesia dan meleburnya ke dalam satu organisasi kepanduan baru bernama Gerakan Pramuka dengan lambang Tunas Kelapa. Gerakan Pramuka dibentuk dengan Keputusan Presiden RI No. 238 Tahun 1961. Meskipun Gerakan Pramuka keberadaannya ditetapkan dengan Keputusan Presiden No. 238 Tahun 1961, namun tanggal 14 Agustus ditetapkan sebagai Hari Pramuka sebab pada tanggal 14 Agustus 1961 secara resmi Gerakan Pramuka diperkenalkan ke khalayak dan Presiden Republik Indonesia menganugerahkan panji-panji Gerakan Pramuka sebagai penghargaan atas kesertaan berjuang untuk kemerdekaan dan pengisian kemerdekaan bangsa dan negara (Katamsi dkk, 2001: 31).

Pada tahun 1999, pemerintah dalam rangka meningkatkan peranan Gerakan Pramuka diperlukan Anggaran Dasar yang mencerminkan aspirasi, visi, dan misi seluruh Gerakan Pramuka Indonesia sehingga secara efektif dapat dijadikan landasan kerja Gerakan Pramuka Indonesia, maka pemerintah mengesahkan Anggaran Dasar Gerakan Pramuka dengan Keputusan Presiden Republik Indonesia No. 34 Tahun 1999 Tentang Pengesahan Anggaran Dasar Gerakan Pramuka sebagai penyempurnaan terhadap Anggaran Dasar yang telah disahkan berdasarkan Keputusan Presiden No. 57 Tahun 1988 Tentang Pengesahan Anggaran Dasar Gerakan Pramuka (Keputusan Presiden Republik Indonesia No. 34 Tahun 1999 Tentang Pengesahan Anggaran Dasar Gerakan Pramuka). Setelah sebelas tahun berlalu, tepatnya pada tahun 2010 
pemerintah menetapkan UU No. 12 Tahun 2010 Tentang Gerakan Pramuka. Beberapa tahun kemudian pemerintah menerbitkan Kurikulum 2013 yang termuat pada Peraturan Pemerintah Republik Indonesia No. 32 Tahun 2013 tentang Perubahan Atas Peraturan Pemerintah No. 19 Tahun 2005 tentang Standar Nasional Pendidikan. Konsekuensi logis atas kebijakan tersebut, yaitu ditetapkannya pendidikan kepramukaan sebagai ekstrakurikuler wajib pada pendidikan dasar dan pendidikan menengah.

\section{KEANGGOTAAN GERAKAN PRAMUKA}

Keanggotaan dalam Gerakan Pramuka dibagi menjadi dua, yaitu anggota biasa dan anggota kehormatan. Anggota biasa Gerakan Pramuka terdiri atas anggota muda dan anggota dewasa, sedangkan anggota kehormatan adalah perorangan yang berjasa luar biasa terhadap Gerakan Pramuka serta diangkat dan dilantik oleh kwartir cabang / kwartir daerah / kwartir nasional (AD/ART Gerakan Pramuka Munas 2013).

\section{Hak dan Kewajiban Anggota}

Setiap anggota Gerakan Pramuka, berhak (AD/ART Gerakan Pramuka Munas Tahun 2013):
a. mengikut pendidikan kepramukaan;
b.mendapatkan sertifikat dan/atau tanda kecakapan kepramukaan;
c. mendapatkan tanda penghargaan;
d.mendapatkan kartu tanda anggota;
e. mengenakan atribut Gerakan Pramuka;
f. memilih dan dipilih dalam jabatan organisasi; dan
g. melakukan pembelaan dan memperoleh perlindungan.

Maksud dari "pembelaan”, adalah, anggota Gerakan Pramuka yang diberhentikan, karena dinilai melanggar Kode Kehormatan Pramuka atau merugikan nama baik Gerakan Pramuka berhak membela dirinya dalam sidang dewan kehormatan di kwartir yang bersangkutan. Apabila anggota Gerakan Pramuka yang bersangkutan tidak menerima keputusan dewan kehormatan di kwartir yang 
bersangkutan dapat mengajukan banding ke dewan kehormatan kwartir satu tingkat di atasnya secara berjenjang. Sedangkan, yang dimaksud "perlindungan", yaitu anggota Gerakan Pramuka dalam melaksanakan kegiatan berhak mendapatkan perlindungan asuransi dan bantuan hukum. Premi asuransi ditanggung oleh masing-masing anggota serta bantuan hukum diupayakan oleh kwartir yang bersangkutan (AD/ART Gerakan Pramuka Munas Tahun 2013).

Setiap anggota Gerakan Pramuka, berkewajiban:

a. melaksanakan Kode Kehormatan Pramuka dan menaati segala ketentuan yang berlaku di lingkungan Gerakan Pramuka;

b. menjunjung tinggi harkat dan martabat Gerakan Pramuka;

c. membayar iuran anggota Gerakan Pramuka.

\section{Anggota Muda}

Anggota muda terdiri atas Pramuka Siaga, Pramuka Penggalang, Pramuka Penegak, dan Pramuka Pandega. Pertama, Pramuka Siaga merupakan jenjang pendidikan yang menekankan pada terbentuknya kepribadian dan keterampilan di lingkungan keluarga melalui kegiatan bermain sambil belajar. Kedua, Pramuka Penggalang merupakan jenjang pendidikan yang menekankan pada terbentuknya kepribadian dan keterampilan dalam rangka mempersiapkan diri untuk terjun dalam kegiatan masyarakat melalui pembelajaran belajar sambil melakukan (learning by doing). Ketiga, Pramuka Penegak merupakan jenjang pendidikan yang menekankan pada terbentuknya kepribadian dan keterampilan agar dapat ikut serta membangun masyarakat melalui kegiatan belajar sambil melakukan, bekerja kelompok, dan berkompetisi. Terakhir, Pramuka Pandega merupakan jenjang pendidikan yang menekankan pada terbentuknya kepribadian dan keterampilan agar dapat ikut serta membangun masyarakat melalui kegiatan kepada masyarakat (UU No. 12 Tahun tentang Gerakan Pramuka).

\section{Anggota Dewasa}

Anggota dewasa adalah anggota biasa yang berusia di atas 25 tahun. Anggota dewasa dibagi menjadi dua, yaitu fungsionaris 
organisasi dan nonfungsionaris organisasi. Anggota dewasa yang termasuk fungsionaris organisasi terdiri atas: (a) pembina; (b) pelatih pembina; (c) pembina profesional; (d) pamong saka; (e) instruktur saka; (f) pimpinan satuan karya; (g) pimpinan satuan komunitas; (h) andalan dan pembantu andalan; dan (i) anggota majelis pembimbing, sedangkan anggota dewasa yang bukan fungsionaris organisasi dapat bergabung dalam gugus darma (AD/ART Gerakan Pramuka Munas Tahun 2013).

\section{SISTEM PENDIDIKAN KEPRAMUKAAN INDONESIA}

Sistem among merupakan sistem mendidik agar peserta didik merdeka batin, merdeka pikiran, dan tenaganya. Sistem among merupakan landasan pendidikan kepramukaan yang mengatur hubungan antara pendidik dan peserta didik. Sistem among dilaksanakan dalam bentuk hubungan pendidik dengan peserta didik merupakan hubungan yang khas, yaitu setiap anggota dewasa wajib memperhatikan perkembangan anggota muda secara pribadi agar pembinaan yang dilakukan sesuai dengan tujuan Gerakan Pramuka (AD/ART Gerakan Pramuka Munas Tahun 2013).

Sistem among sebagaimana dimaksud dilaksanakan dengan menerapkan prinsip kepemimpinan (UU No. 12 Tahun 2010 tentang Gerakan Pramuka):

a. Ing ngarso sung tulodha maksudnya di depan menjadi teladan

b. Ing madya mangun karso maksudnya di tengah membangun kemauan

c. Tut wuri handayani maksudnya di belakang mendorong dan memberikan motivasi kemandirian.

Sistem among ialah sistem pendidikan yang berjiwa kekeluargaan dan bersendikan pada dua dasar, yaitu kodrat alam dan kemerdekaan. Kodrat alam sebagai syarat mencapai kemajuan secepat-cepatnya dan sebaik-baiknya. Kodrat alam sebagai manifestasi Tuhan YME mengandung arti pada hakikatnya manusia sebagai makhluk Tuhan adalah satu dengan alam semesta, maka manusia wajib tunduk kepada hukum-hukum alam dan wajib menyatukan serta menyelaraskan diri dirinya dengan kodrat alam. Penyesuaian diri dengan alam tersebut merupakan proses 
pembudayaan manusia (Suparlan, 2015: 67). Kemerdekaan sebagai syarat untuk menghidupkan dan menggerakkan kekuatan lahir-batin anak agar dapat memiliki pribadi yang kuat dan dapat berpikir serta bertindak merderka (Ki Haryadi, 1985: 11).

Suparlan (2015: 73) mengatakan filsafat pendidikan Ki Hajar Dewantara disebut sebagai filsafat pendidikan among yang di dalamnya merupakan konvergensi dari filsafat progresivisme tentang kemampuan kodrati peserta didik untuk mengatasi persoalanpersoalan yang dihadapi dengan memberikan kebebasan berpikir seluas-luasnya. Ki Haryadi (1985: 15) mengatakan sistem among merupakan pendukung dan pelaksana aliran-aliran pendidikan merdeka. Dasar kemerdekaan merupakan keharusan pada tiap usaha pendidikan sehingga iklim pendidikan harus bersuasanakan kemerdekaan pula. Setiap peserta didik wajib diberi kemerdekaan sejauh mereka dapat melaksanakannya dengan segenap kesadaran dan kecakapan serta mampu memanfaatkan kemerdekaan tersebut bagi kepentingan pribadi dan masyarakat.

Sistem among menggunakan sistem pemeliharaan dengan sebesar perhatian untuk mendapat tumbuhnya hidup anak, baik lahir dan batin menurut kodratnya sendiri. Sistem among dilandasi oleh sikap cinta kasih, saling menghormati, menghargai, demokratis, tidak ingin menguasai dan menundukkan orang lain untuk kepentingan pribadi atau golongan tertentu (Dewantara, 1994: 28). Yang menonjol dari sistem among adalah penempatan anak sebagai figur sentral dalam proses pendidikan, sedangkan pamong ditempatkan sebagai pembimbing yang dengan sepenuh jiwa mengabdikan hidupnya bagi kepentingan sang anak. Kodrat atau fitrah anak sebagai manusia yang diberi keleluasaan bertumbuh dan berkembang sehingga anak dapat dihantarkan menuju kea rah kemerdekaan lahir dan batin dan mampu menjadi manusia yang berarti bagi dirinya sendiri dan orang lain (Ki Gunawan, 1989: 31).

\section{MODEL PENDIDIKAN KEPRAMUKAAN INDONESIA Model Blok}

Model blok memiliki karakteristik sebagai berikut (Peraturan 
Menteri Pendidikan dan Kebudayaan No. 63 Tahun 2014 tentang Pendidikan Kepramukaan sebagai Ekstrakurikuler Wajib Pada Pendidikan Dasar dan Pendidikan Menengah).

a. Diikuti oleh seluruh siswa.

b. Dilaksanakan pada setiap awal tahun pelajaran.

c. Untuk kelas I, kelas VII, dan kelas X diintergrasikan di dalam Masa Pengenalan Lingkungan Sekolah (MPLS).

d. Untuk SD/MI dilaksanakan selama 18 jam, SMP/MTs dan SMA/MA/SMK/MAK dilaksanakan selama 36 jam.

e. Penanggungjawab kegiatan adalah Kepala Sekolah selaku Ketua Mabigus

f. Pembina kegiatan adalah Guru Kelas / Guru Mata Pelajaran selaku Pembina Pramuka dan / atau Pembina Pramuka serta dapat dibantu

g. Pembina Pramuka (Instruktur Muda / Instruktur Pramuka).

Tabel 4. Model Pendidikan Kepramukaan Indonesia

\begin{tabular}{|l|l|l|l|}
\hline No. & Nama Model & \multicolumn{1}{|c|}{ Sifat } & \multicolumn{1}{c|}{$\begin{array}{c}\text { Pegorganisasian } \\
\text { Kegiatan }\end{array}$} \\
\hline 1. & Model Blok & $\begin{array}{l}\text { Wajib, setahun sekali, } \\
\text { berlaku bagi seluruh } \\
\text { peserta didik, } \\
\text { terjadwal, penilaian } \\
\text { umum }\end{array}$ & $\begin{array}{l}\text { Kolaboratif } \\
\text { - Bersifat intramural } \\
\text { atau ekstramural } \\
\text { (di luar dan/atau } \\
\text { didalam lingkungan } \\
\text { satuan pendidikan) }\end{array}$ \\
\hline 2. & $\begin{array}{l}\text { Model } \\
\text { Aktualisasi }\end{array}$ & $\begin{array}{l}\text { Wajib, rutin, terjadwal, } \\
\text { berlaku untuk seluruh } \\
\text { peserta didik dalam } \\
\text { setiap kelas, } \\
\text { penjadwalan, dan } \\
\text { penilaian formal }\end{array}$ & $\begin{array}{l}\text { Pembina Pramuka } \\
\text { Bersifat intramural } \\
\text { (dalam lingkungan } \\
\text { satuan pendidikan) }\end{array}$ \\
\hline 3. & $\begin{array}{l}\text { Reguler di } \\
\text { Gugus Depan }\end{array}$ & $\begin{array}{l}\text { Sukarela, berbasis } \\
\text { minat }\end{array}$ & $\begin{array}{l}\text { Sepenuhnya dikelola } \\
\text { oleh Gugus Depan } \\
\text { Pramuka pada satuan } \\
\text { pendidikan. }\end{array}$ \\
\hline
\end{tabular}

Sumber: Peraturan Menteri Pendidikan dan Kebudayaan RI No. 63 Tahun 2014

Prosedur pelaksanaan model blok pendidikan kepramukaan sebagai ekstrakurikulr wajib sebagai berikut (Peraturan Menteri Pendidikan dan Kebudayaan No. 63 Tahun 2014 tentang Pendidikan 
Kepramukaan sebagai Ekstrakurikuler Wajib Pada Pendidikan Dasar dan Pendidikan Menengah).

a. Peserta didik dibagi dalam beberapa kelompok, setiap kelompok didampingi oleh pembina pramuka atau pembantu pembina pramuka.

b. Pembina pramuka melaksanakan kegiatan orientasi pendidikan kepramukaan.

c. Guru kelas/guru mata pelajaran yang bukan pembina pramuka membantu pelaksanan kegiiatan orientasi pendidikan kepramukaan.

\section{Model Aktualisasi}

Model aktualisasi memiliki karakteristik sebagai berikut.

a. Diikuti oleh seluruh siswa.

b. Dilaksanakan setiap satu minggu sekali.

c. Setiap satu kali kegiatan dilaksanakan selama 120 menit.

Prosedur pelaksanaan model aktualisasi kurikulum 2013 pendidikan kepramukaan sebagai ekstrakurikuler wajib sebagai berikut (Peraturan Menteri Pendidikan dan Kebudayaan No. 63 Tahun 2014 tentang Pendidikan Kepramukaan sebagai Ekstrakurikuler Wajib Pada Pendidikan Dasar dan Pendidikan Menengah).

a. Guru kelas / guru mata pelajaran mengidentifikasi muatanmuatan pembelajaran yang dapat diaktualisasikan dalam kegiatan kepramukaan.

b. Guru menyerahkan hasil identifikasi muatan-muatan pembelajaran kepada pembina untuk dapat diaktualisasikan dalam kegiatan kepramukaan.

c. Setelah pelaksanaan kegiatan kepramukaan, pembina menyampaikan hasil kegiatan kepada guru kelas / guru mata pelajaran.

\section{Reguler di Gugus Depan}

Model reguler di gugus depan memiliki karakteristik sebagai berikut (Peraturan Menteri Pendidikan dan Kebudayaan No. 63 Tahun 2014 tentang Pendidikan Kepramukaan sebagai 
Ekstrakurikuler Wajib Pada Pendidikan Dasar dan Pendidikan Menengah).

a. Diikuti oleh siswa yang berminat mengikuti kegiatan Gerakan Pramuka di dalam gugus depan.

b. Pelaksanaan kegiatan diatur oleh masing-masing gugus depan

\section{DEHUMANISASI PENDIDIKAN KEPRAMUKAAN INDONE-SIA}

Dehumanisasi yang terdapat pada model pendidikan kepramukaan Indonesia tidak sepenuhnya dari awal pendidikan kepramukaan dibentuk pada tahun 1961 hingga sekarang. Dehumanisasi pada pendidikan kepramukaan Indonesia terjadi ketika ditetapkannya Peraturan Menteri Pendidikan dan Kebudayaan No. 63 Tahun 2014 tentang Pendidikan Kepramukaan sebagai Ekstrakurikuler Wajib pada Pendidikan Dasar dan Menengah, khususnya pendidikan kepramukaan dengan model blok dan aktualisasi yang terdapat pada peraturan tersebut. Hal ini dikarenakan kesukarelaan dan kebebasan peserta didik diciderai dengan unsur paksaan untuk wajib mengikuti pendidikan kepramukaan yang nantinya nilai yang diperoleh pada kegiatan pendidikan kepramukaan sebagai ekstrakurikuler wajib berpengaruh terhadap kenaikan kelas peserta didik serta adanya penambahan tugas yang semestinya bukan tupoksi pembina, yakni mengaktualisasikan muatan pembelajaran yang terdapat di sekolah yang bersifat formal ke dalam pendidikan kepramukaan yang bersifat informal. Dehumanisasi yang terdapat pada model pendidikan kepramukaan Indonesia bukanlah dehumanistik yang bersifat mutlak sebab secara tidak langsung model pendidikan kepramukaan Indonesia secara umum turut berkontribusi terhadap pengembangan PPK (Penguatan Pendidikan Karakter).

Peraturan pendidikan kepramukaan sebagai ekstrakurikuler wajib pada pendidikan dasar dan pendidikan menengah tidak membuat peserta didik sebagai seorang manusia hidup sebagaimana mestinya subjek yang memiliki hak atas keberadaan hidupnya. Peserta didik merupakan makhluk historis yang menciptakan dan 
tercipta dari sejarah tentu melahirkan konsekuensi logis yang menjadikan peserta didik sebagai subjek atas penamaan dunia yang menyingkap hubungan antara manusia dan dunia. Peserta didik mengalami keterasingan sehingga eksistensi peserta didik dibawah eksistensi pihak lain.

Penindasan yang terjadi pada implementasi model pendidikan kepramukaan sebagai ekstrakurikuler wajib merupakan bagian dari dehumanisasi pendidikan sebab panggilan manusia sejati adalah manusia yang sadar dan bertindak mengatasi dunia serta realitas yang menindas. Namun disisi lain, nilai-nilai pendidikan kepramukaan Indonesia secara umum merupakan nilai yang membawa pembina dan peserta didik menuju tujuan pendidikan yang humanis sehingga dehumanisasi pendidikan kepramukaan Indonesia bersifat parsial pada beberapa aspek tertentu.

Peserta didik dan pembina memiliki panggilan ontologis untuk menjadi semakin manusiawi. Manusia harus menciptakan kembali dirinya sebagai subjek dengan refleksi yang berkesinambungan, karena peserta didik dan pembina sebagai subjek pendidikan merupakan panggilan. Terlebih lagi sistem among yang dilaksanakan pada kegiatan pendidikan kepramukaan merupakan proses pendidikan yang membentuk peserta didik agar berjiwa merdeka, disiplin, dan mandiri dalam hubungan timbal balik antarmanusia.

Subjek (elit kalangan dominan) dalam hal ini lebih ditekankan pada pembuat kebijakan (Kementerian Pendidikan dan Kebudayaan) mengobjektivikasi pembina dan peserta didik (kaum tertindas sebagai bagian realitas) serta menjadikan upaya memperkuat proses pembentukan karakter bangsa yang berbudi pekerti luhur yang sesuai dengan nilai dan moral Pancasila melalui pendidikan kepramukaan sebagai ekstrakurikuler wajib menjadi realitas yang dipertahankan (objek).

Peraturan pendidikan kepramukaan sebagai ekstrakurikuler wajib merupakan peraturan yang melengkapi kebijakan Kurikulum 2013 kemudian dikembangkan dengan landasan filosofis yang memberikan dasar bagi pengembangan seluruh potensi peserta didik sebagai manusia Indonesia yang berkualitas sebagaimana tercantum dalam tujuan pendidikan nasional justru membelenggu potensi dan 
otonomi peserta didik. Proses pembentukan karakter bangsa yang berbudi pekerti luhur yang sesuai dengan nilai dan moral Pancasila memang diperlukan dan penting, terlebih Pancasila merupakan dasar falsafah Negara Kesatuan Republik Indonesia, namun bukan berarti kemudian menjadikan pendidikan kepramukaan sebagai ekstrakurikuler wajib sebab pada hakikatnya kegiatan ekstrakurikuler merupakan perangkat operasional yang bersifat opsional untuk menjembatani kebutuhan perkembangan peserta didik yang berbeda, seperti perbedaan akan nilai moral, sikap, kemampuan, dan kreativitas.

Berdasarkan tiga model pendidikan kepramukaan yang terdapat Peraturan Menteri Pendidikan dan Kebudayaan No. 63 Tahun 2014, sebaiknya model pendidikan kepramukaan diwujudkan dalam model regular di gugus depan yang diikuti oleh siswa yang berminat mengikuti kegiatan di dalam gugus depan serta pelaksanaan kegiatan diatur oleh masing-masing gugus depan. Model reguler di gugus depan secara esensial juga mengembalikan pendidikan kepramukaan sebagai ekstrakurikuler pilihan yang berbasis pada bakat dan minat peserta didik.

Model pendidikan kepramukaan Indonesia yang humanis terwujud ketika peserta didik itu dikembalikan seperti dahulu yakni pendidikan kepramukaan sebagai ekstrakurikuler pilihan sebab kesukarelaan dan kemerdekaan pembina dan peserta didik sebagai manusia otonom tidak dicederai sehigga pembina dan peserta didik ditempatkan sesuai dengan harkat dan martabat kemanusiaannya. Dasar kemerdekaan merupakan keharusan dalam pendidikan kepramukaan Indonesia sebab kemerdekaan merupakan syarat untuk membantu perkembangan segala potensi kodrati tanpa tekanan dan hambatan sehingga memungkinkan perkembangan pribadi yang kuat dan berjiwa merdeka.

\section{PRAKTIK PENDIDIKAN HADAP-MASALAH DALAM PENDIDIKAN PENDIDIKAN KEPRAMUKAAN}

Model pendidikan kepramukaan Indonesia secara umum sebagaimana terdapat dalam AD/ART Gerakan Pramuka Munas Tahun 2013 merupakan cerminan dari pendidikan hadap-masalah 
yang menjawab kesadaran serta mengatasi kontradiksi antara pembina dan peserta didik dengan situasi pembelajaran dialogis sehingga terwujud proses komunikasi timbal-balik serta terdapat ruang demokratis untuk saling mengkritisi. Pembina tidak lagi menjadi orang yang mengajar, tetapi juga orang yang mengajar dirinya sendiri melalui dialog dengan peserta didik. Hal ini didapati pada sistem among yang terdapat pada pendidikan kepramukaan yang mengatur hubungan antara pembina (pamong) dengan peserta didik sebagai hubungan yang khas serta kesadaran diri pamong dalam mengabdikan dirinya tanpa ada keinginan untuk menguasai.

Tidak ada lagi subjek maupun objek dalam model pendidikan kepramukaan Indonesia sebab yang ada hanyalah subjek sekaligus objek manusia (pembina dan peserta didik) yang saling mengajar. Manusia hidup di dunia bersama-sama dengan manusia lain sehingga penemuan dirinya sebagai subjek membawa implikasi penemuan atas subjektivitas sesama manusia. Tindakan-tindakan yang manusiawi mengarah pada komunikasi melalui dialog dengan sesama untuk menentukan bagaimana mereka mengalami kenyataan sehingga manusia dapat bertindak atas sejarah secara bersama-sama.

Proses pembelajaran yang terdapat pada model pendidikan kepramukaan Indonesia juga mengembangkan kemampuan manusia (pembina dan peserta didik) untuk memahami secara kritis manusia mengada dalam dunia serta memperlakukan murid sebagai pemikir yang kritis. Hal ini dapat dilihat pada metode pendidikan kepramukaan yang menerapkan metode belajar sambil melakukan (learning by doing), kegiatan di alam terbuka yang mengandung pendidikan yang sesuai dengan perkembangan jasmani dan rohani peserta didik, serta kemitraan dengan anggota dewasa. Teknik penerapan pendidikan kepramukaan yang berbasis pada praktik langsung, perjalanan, widya wisata, simulasi, dan napak tilas secara tidak langsung mendorong sikap kritis peserta didik dan tampak pembina (pamong) memperlakukan peserta didik sebagai manusia yang otonom dan kritis.

Ketika model pendidikan kepramukaan Indonesia kemudian ditetapkan sebagai ekstrakurikuler wajib, maka praktik pendidikan hadap-masalah yang sebelumnya telah ada menjadi terdistorsi, 
karena ada unsur penindasan berupa paksaan dan ketidaksukarelaan, baik itu pada pembina maupun peserta didik. Distorsi yang terdapat pada model pendidikan kepramukaan Indonesia secara tidak langsung mengarahkan pendidikan kepramukaan sebagai ekstrakurikuler wajib pada praktik pendidikan penindasan sebab peserta didik menjadi terobjektivikasi, menghalang-halangi kreativitas, dan menjinakan intensionalitas kesadaran dengan cara mengisolasi kesadaran itu dari dunia sehingga menolak menjadi manusia seutuhnya, serta teori dan praktik pendidikan kepramukaan sebagai ekstrakurikuler wajib merupakan kekuatan yang membelenggu dan menekan sehingga membuat ketidakmampuan dalam menampilkan manusia sebagai makhluk yang menyejarah.

\section{KONSIENTISASI DALAM PENDIDIKAN KEPRAMUKAAN}

Konsietisasi yang terdapat dalam model pendidikan kepramukaan Indonesia ketika ditetapkan sebagai ekstrakurikuler wajib pada fase penamaan cenderung berada pada kesadaran magis sebab manusia pada kesadaran magis dapat dikatakan sebagai manusia pasif yang hanya menerima realitas. Manusia (pembina dan peserta didik) pada fase kesadaran magis menyesuaikan diri dengan kehidupan tempat tinggalnya. Dehumanisasi yang terdapat pada model pendidikan kepramukaan Indonesia disebabkan oleh kekuasaan-kekuasaan yang di luar jangkauan mereka (pembuat kebijakan).

Model pendidikan kepramukaan sebagai ekstrakurikuler wajib dalam fase penamaan mengarah pada penolakan masalah dengan menghindari masalah dehumanisasi peserta didik dan empati pada penindas sebab pendidikan kepramukaan sebagai ekstrakurikuler wajib memiliki aspek legalitas yang jelas sehingga yang perlu dilakukan oleh pembina serta peserta didik adalah menjalankan peraturan tersebut sebagaimana mestinya terlebih pendidikan kepramukaan sebagai ekstrakurikuler wajib memiliki koherensi dengan tujuan Gerakan Pramuka dalam hal keduanya mengusung komitmen kuat terhadap pengembangan sikap spiritual, sikap sosial, dan keterampilan/kecakapan sebagai insan dan warga negara Indonesia dalam konteks nilai dan moral Pancasila. Pelaksana 
pendidikan kepramukaan pada akhirnya berusaha memahami pola pikir dan niat baik pemerintah (pembuat peraturan) terkait dengan pengembangan model pendidikan kepramukaan di Indonesia.

Sementara itu, pada fase berpikir dan aksi cenderung berada pada kesadaran naif. Masyarakat yang turut serta berperan dalam pendidikan kepramukaan Indonesia menganggap sistem dan struktur yang ada sudah baik dan benar serta hal tersebut merupakan faktor given, maka tidak perlu tindakan kritis untuk mempertanyakan lagi.

Model pendidikan kepramukaan sebagai ekstrakurikuler wajib dalam fase berpikir mengarah pada menyalahkan sesama kaum tertindas dengan menerima penjelasan penindas dan mengetahui maksud penindas. Penjelasan terkait dengan peraturan pendidikan kepramukaan sebagai ekstrakurikuler wajib diterima dan dipenuhi oleh kaum tertindas (pelaksana dan objek pendidikan kepramukaan) terkait dengan aspek legalitas dan tujuan pendidikan yang jelas serta menganggap pihak-pihak yang kontra dengan peraturan pendidikan kepramukaan sebagai ekstrakurikuler wajib dianggap sebagai pihak yang tidak memahami esensi pendidikan, berseberangan dengan Pancasila dan tidak taat pada peraturan yang berlaku.

Pada fase aksi, perkembangan proses konsientisasi mengarah pada aktif kerja sama dengan penindas (kolusi) dengan memenuhi keinginan penindas. Kerja sama dalam rangka pemenuhan keinginan penindas terlihat pada kesepakatan Gerakan Pramuka dalam melaksanakan proses kegiatan pendidikan kepramukaan sebagai ekstrakurikuler wajib yang dirancang oleh Kementerian Pendidikan dan Kebudayaan meskipun pada beberapa hal kebijakan tersebut telah menyalahi hakikat dan praktik pendidikan kepramukaan Indonesia.

Fase perkembangan proses konsientisasi yang terdapat pada model kepramukaan Indonesia yang telah diuraikan sebelumnya nantinya tidak seluruhnya tetap dan tidak seluruhnya berubah. Harus diakui manusia bergerak dari keadaan keterasingan menuju humanisasi tidak terjadi seketika, namun terjadi secara bertahap. Perubahan-perubahan yang terjadi merupakan hasil kreatif dari manusia sebelumnya. Struktur tertentu bukanlah sesuatu yang permanen, melainkan proses perubahan muncul sebagai penciptaan 
kembali atas tindakan-tindakan sebelumnya.

\section{DIALOG DALAM PENDIDIKAN KEPRAMUKAAN}

Hakikat model pendidikan kepramukaan Indonesia secara umum merupakan pendidikan yang bersifat dialogis dengan hubungan intersubjektivitas, yakni hubungan antarmanusia yang saling menghormati dan berkomunikasi dalam suasana simpatik terhadap gagasan subjek lain. Namun, pada saat model pendidikan kepramukaan Indonesia ditetapkan sebagai ekstrakurikuler wajib justru membuat unsur-unsur dialogis yang terdapat pada pendidikan kepramukaan terdistorsi sehingga beberapa unsur pendidikan kepramukaan menjadi anti-dialogis yang tidak menjadikan manusia sebagai subjek.

Unsur kerja sama, kesatuan, dan sintesis kultural dalam model pendidikan kepramukaan Indonesia terdapat pada penerapan sistem kelompok (beregu) dan kegiatan di alam terbuka mengandung pendidikan yang sesuai dengan perkembangan jasmani dan rohani. Sistem kelompok dan kegiatan di alam terbuka menjadi pembina dan peserta didik harus bekerja sama dengan mengandalkan kepercayaan dan mengidentifikasi bersama peserta didik sehingga membebaskan subjek (pembina dan peserta didik) dari pendidikan yang membelenggu realitas serta menaifkan kesadaran. Pendidik tidak datang sebagai orang menyerang dan menjinakan, tetapi orang yang belajar bersama peserta didik mengenai dunianya serta realitas realitas sesungguhnya sehingga pendidik dan peserta didik dapat mengidentifikasikan diri kemudian melihat garis-garis besar bagi karyanya.

Unsur organisasi dalam model pendidikan kepramukaan Indonesia terdapat pada kemitraan antara anggota muda (peserta didik) dengan anggota dewasa (pembina) dan sistem satuan terpisah putra dan putri. Kemitraan antara pembina dan peserta didik memperlihatkan kenyataan perjuangan bagi pembebasan merupakan tugas bersama (pembina dan peserta didik). Namun, pada ruang lingkup lebih luas ketika pendidikan kepramukaan ditetapkan sebagai ekstrakurikuler wajib justru memunculkan manipulasi sehingga terjadi serangan budaya. Peserta didik dibuat menyesuaikan 
diri dengan tujuan-tujuan dari pembuat kebijakan yang anti-dialog. Pendidikan kepramukaan sebagai ekstrakurikuler wajib memaksakan pandangan dunianya sendiri kepada peserta didik sehingga menghambat kreativitas dengan mengendalikan kebebasan dan otonomi peserta didik.

\section{SIMPULAN}

Berdasarkan pembahasan dan analisis yang telah dipaparkan, peneliti dapat menarik kesimpulan sebagai berikut:

1. Pendidikan kepramukaan merupakan proses belajar mandiri yang progresif bagi kaum muda untuk mengembangkan diri menjadi pribadi seutuhnya. Pendidikan kepramukaan sebagai pendidikan nonformal dalam sistem pendidikan sekolah yang dilakukan di alam terbuka dengan menerapkan Prinsip Dasar Kepramukaan dan Metode Kepramukaan agar terbentuk kepribadian dan watak yang berakhlak mulia, mandiri, peduli, cinta tanah air, serta memiliki kecakapan hidup. Kegiatan pendidikan kepramukaan dilaksanakan dengan sistem among.

2. Konsep filsafat pendidikan Paulo Freire merupakan konsep pendidikan pembebasan. Tujuan akhir atas keberadaan manusia adalah proses humanisasi, yaitu memanusiakan manusia. Pendidikan pembebasan merupakan kegiatan belajar bersama antara guru dan murid melalui perantara dunia. Pendidikan tidak sekadar pengajaran, melainkan dialog antara guru dan murid, karena dialog adalah unsur fundamental. Freire memahami konsientisasi sebagai usaha pembebasan serta kegiatan untuk mengetahui secara kritis. Konsientisasi merupakan proses menjadi manusia seutuhnya. Proses konsientisasi dibagi menjadi tiga fase, yaitu kesadaran magis, kesadaran naif, dan kesadaran kritis. Dalam pendidikan pembebasan, dialog bukanlah dialog yang dilakukan oleh guru untuk murid atau sebaliknya, tetapi memengaruhi dan menantang keduanya sehingga melahirkan pandangan dan pendapat mereka tentang dunia.

3. Model pendidikan kepramukaan Indonesia mengalami dehumanisasi pada saat ditetapkannya Peraturan Menteri 
Pendidikan dan Kebudayaan No. 63 Tahun 2014 tentang Pendidikan Kepramukaan sebagai Ekstrakurikuler Wajib pada Pendidikan Dasar dan Pendidikan Menengah. Ketika model pendidikan kepramukaan Indonesia kemudian ditetapkan sebagai ekstrakurikuler wajib, maka praktik pendidikan hadap-masalah yang sebelumnya telah ada menjadi terdistorsi. Konsientisasi yang terdapat dalam model pendidikan kepramukaan Indonesia ketika ditetapkan sebagai ekstrakurikuler wajib pada fase penamaan cenderung berada pada kesadaran magis. Sementara itu, pada fase berpikir dan aksi cenderung berada pada kesadaran naif. Hakikat model pendidikan kepramukaan Indonesia secara umum merupakan pendidikan yang bersifat dialogis dengan hubungan intersubjektivitas. Namun, pada saat model pendidikan kepramukaan Indonesia ditetapkan sebagai ekstrakurikuler wajib justru membuat unsur-unsur dialogis yang terdapat pada pendidikan kepramukaan terdistorsi sehingga beberapa unsur pendidikan kepramukaan menjadi anti-dialogis yang tidak menjadikan manusia sebagai subjek.

\section{DAFTAR PUSTAKA}

Collins, D.E. 1999. Paulo Freire: Kehidupan, Karya, dan Pemikirannya. Terj. Henry Heynerardhi dan Anastasia P. Yogyakarta: Pustaka Pelajar \& Komunitas APIRU Yogyakarta.

Dewantara, K.H. 1994. Kebudayaan. Yogyakarta: Majelis Luhur Persatuan Taman Siswa

Freire, P. 1999. Politik Pendidikan. Terj. Agung Prihantoro dan Fuad Arif Fudiyanto. Yogyakarta: Pustaka Pelajar. . 2008. Pendidikan Masyarakat Kota. LkiS. Yogyakarta.

Huda, N. 2013. Kebijakan Sesat: Pramuka dalam Kurikulum 2013. https://www.tempo.co/read/kolom/2013/10/09/833/KebijakanSesat-Pramuka-dalam-Kurikulum-2013. Diakses pada tanggal 1 Februari 2017 pukul 16.04 WIB.

Katamsi, A. dkk. 2001. 40 Tahun Gerakan Pramuka. Jakarta: Kwartir Nasional Gerakan Pramuka.

Ki Haryadi. 1985. Sistem Among: Dari Sistem Pendidikan ke Sistem Sosial. 
Yogyakarta: Majelis Luhur Taman Siswa.

Ki Gunawan. 1989. Ki Hajar Dewantara Dalam Pandangan Para Cantrik dan Mentriknya. Yogyakarta: Majelis Luhur Persatuan Taman Siswa.

Kwartir Nasional Gerakan Pramuka. 2013. AD/ART Gerakan Pramuka Hasil Keputusan Musyawarah Nasional Tahun 2013. Jakarta: Kwartir Nasional Gerakan Pramuka.

Menteri Pendidikan dan Kebudayaan Republik Indonesia. 2014. Peraturan Menteri Pendidikan dan Kebudayaan Republik Indonesia No. 63 Tahun 2014 Tentang Pendidikan Kepramukaan sebagai Ekstrakurikuler Wajib Pada Pendidikan Dasar dan Pendidikan Menengah. Jakarta: Kementerian Pendidikan dan Kebudayaan Republik Indonesia.

Murtiningsih, S. 1995. Konsep Pendidikan Alternatif Paulo Freire: Sebuah Perspektif bagi Persoalan Pendidikan. Skripsi. Yogyakarta: Universitas Gadjah Mada. . 2004. Pendidikan Alat Perlawanan: Teori Pendidikan Radikal Paulo Freire. Yogyakarta: Resist Book.

Presiden Republik Indonesia. 1999. Keputusan Presiden Republik Indonesia No. 34 Tahun 1999 Tentang Pengesahan Anggaran Dasar Gerakan Pramuka. Jakarta: Kementerian Sekretariat Negara Republik Indonesia . 2010. Undang-undang No. 12 Tahun 2010

Tentang Gerakan Pramuka. Jakarta: Kementerian Sekretariat Negara Republik Indonesia

Indonesia No. 87 Tahun 2017 Tentang Penguatan Pendidikan Karakter. Jakarta: Kementerian Sekretariat Negara Republik Indonesia.

Shor, I. dan Paulo Freire. 2001. Menjadi Guru Merdeka: Petikan Pengalaman. Yogyakarta: LKiS.

Smith, W. 2008. Conscientizacao: Tujuan Pendidikan Paulo Freire. Yogyakarta: Pustaka Pelajar.

Suparlan, H. 2015. Filsafat Pendidikan Ki Hajar Dewantara dan Sumbangannya bagi Pendidikan Indonesia. Yogyakarta: Jurnal Filsafat Universitas Gadjah Mada. 25 (1). 56-74. 